\title{
Philosophy as Spiritual Exercise in an Adult Literacy Course
}

\section{Walter Kohan \& Jason Wozniak}

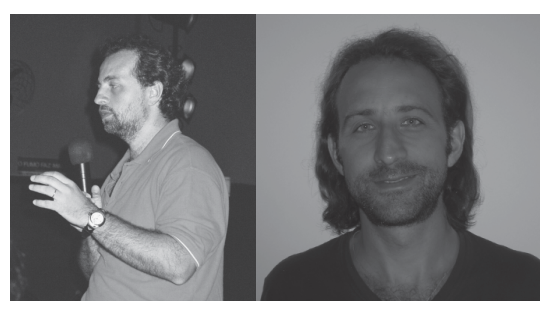

\section{Introduction}

$\mathrm{T}$ his narrative describes and problematizes one year (2007-2008) of educational and philosophical work with illiterate adults in contexts of urban poverty in the Public School Joaquim da Silva Peçanha, located in the city of Duque de Caxias, a suburb of the State of Rio de Janeiro, Brasil. The project, "Em Caxias a Filosofia En-caixa?!" ("Does Philosophy fit in Caxias?!"), involved a teacher education program in which public school teachers studied and practiced the art of conducting philosophical experiences with their students, and the authors' experimentation with philosophical experiences in an adult literacy class. This narrative concerns the latter aspect of the project. The thirty students and two teachers involved in the course did not study the history of philosophy, nor did they create philosophical systems or theories. Rather, they participated in a philosophical experience that might best be understood by examining Pierre Hadot's concept of philosophy "as a way of life" - a notion as old as Socrates. In the Apology, when defending himself against the accusations leveled against him by his fellow Athenians, Socrates uses the word "philosophy" not as a noun, but rather as an infinitive verb (29c) and as an adverb (23d; 28e; 29d) that qualifies his manner of living, for which he is being persecuted. Philosophy then, appears to be a kind of practice, a form of living in which one "examines oneself and others" (Apology 28e).

The "philosophical way of living" practiced by adults in a public school literacy class is discussed and examined in this narrative. The narrative also aims to demonstrate that: a) a "philosophical way of living" can be practiced by any adult regardless of literacy ability or number of years of formal education; b) philosophy as a lived experience can be a transformative practice that contributes to what Paulo Freire calls "the reading of the world" and is thus an epistemological and political condition of critical political literacy; c) there is a reciprocal relationship between dialogue and a "philosophical way of living" such that each cultivates the other; and d) in spite of conditions, tensions and challenges, there is indeed space within schools to inspire and nurture a "philosophical

Jason Thomas Wozniak, Member, Center of Philosophical Studies of Childhood (NEFI), State University of Rio de Janeiro (UERJ).

Walter Omar Kohan, Member, NEFI; Professor, UERJ; Researcher, National Council of Research (CNPq) and the Research Foundation of the State of Rio de Janeiro (FAPERJ) way of living." Put another way, even if there is no formally recognized space for a "philosophical way of living" in schools, assuming this possibility can generate appealing spaces for transformative practices in such institutions.

\section{"Em Caxias a Filosofia en-caixa? A Public School Gambles on Thinking"}

The philosophical experiences under investigation in this paper occurred in Duque de Caxias, a sprawling city of 870,000 inhabitants roughly 30 minutes outside the city Rio de Janeiro. Joaquim da Silva Peçanha Public School serves one of the socio-economically depressed zones of the city. The school consists of around 800 students aged 6 to 70 years old, and functions from 7:00 am until 10:00 pm five days a week. In 2007 the school administration and nine teachers from the school decided to begin work with the Center of Philosophical Studies of Childhood (NEFI) at the State University of Rio de Janeiro (UERJ) on a project that aimed to create and nurture philosophical experiences in the school's classrooms. The project, "Does Philosophy fit in Caxias?! A Public School Gambles on Thinking," involved six members of NEFI working with individual teachers for one year inside and outside of their classrooms. Several workshops - between 20 and 40 hours each - were offered by members of NEFI during the first year of the project. On a weekly basis seven teachers involved in the project philosophized with children (ages 6 to 15) in their classrooms. Two other teachers, Graça and Monica, coordinated a weekly philosophy class with 30 adult students (ages 17 to 70) enrolled in a nightly literacy course.

The majority of the students enrolled in the adult literacy class worked full-time during the day and studied at night. Many were emigrants from other states in Brazil who had migrated with their families to the state of Rio in search of work. Enrollment in the literacy class did not mean that students had to participate in the weekly, one-hour philosophy class. Attendance was optional, and all students were asked to give their oral consent before the year-long course began. No student had ever taken a philosophy course before. Many, we later discovered, had no idea what the word "philosophy" could mean when they had agreed to participate. Nonetheless, attendance during the course was consistently over $90 \%$ and the majority of students enthusiastically requested to continue with the course in the 2009-2010 academic year. In fact, as we write this paper (November 2009) a dozen teachers from three other schools within the same school district have joined the project, with support from their municipal Secretary of 
Education. A new group of adults has entered the project, and has participated in philosophical activities in their school and at the State University as well.

\section{Philosophy as Spiritual Exercise}

The question "What is philosophy?" like all philosophical questions, is an open and controversial one. Each philosophical enterprise has its own way of answering it. Even though it is endlessly open, an examination of two major works from Pierre Hadot, What is Ancient Philosophy? (2002) and Philosophy as a Way of Life (1995) reveals an approach to answering this question that has been very meaningful throughout the history of philosophy, and also for our work: philosophy can be conceived of as a number of spiritual exercises that transform the way we see and live in the world.

In what follows, the nature of philosophical spiritual exercises as presented by Hadot are briefly summarized and examined in the context of the project just described. By re-visiting one year's worth of philosophical experiences with a group of adult learners we can outline and ruminate on the characteristics of spiritual exercises and how they contribute to a "philosophical way of living" in adult education courses. More broadly, we can consider how the practice of philosophical spiritual exercises can nurture more dialogical relationships with oneself and with others. Finally, we consider how practicing philosophical spiritual exercises has significant political consequences.

There is a classic and significant difference between learning the history of philosophy, or being introduced to philosophies as theoretical discourses and philosophers' systems, and actually practicing philosophy (Hadot 2002, pp.2-6). The former typically demands that students begin studying the classic philosophical works written by the great thinkers of ancient Greece and work their way chronologically to the influential thoughts and texts of today's contemporary philosophers. Along this linear and chronological trajectory students are exposed to different sorts of explanations meant to interpret and give account of theoretical discourses. There is of course a strong value in learning this philosophical tradition and, to some extent, any rigorous engagement with philosophy needs to take into consideration that tradition. If philosophy is an "on-going conversation" in a Rortyan sense, there is no way to enter that conversation without being aware of its history. Nevertheless, frequently teaching and learning the philosophical tradition becomes an end in itself, and too often this path of study cuts short philosophy as an existential experience or practice.

In contrast to this academic approach, Hadot has demonstrated that philosophy is above all a way of life, one that demands an askesis, a Greek word meaning "exercise" or "practice," and is capable of transforming the individual engaged in it. Thought of in this way, philosophy is a spiritual exercise that intends to effect a modification and transformation in the subject that practices it (Hadot 2002, p.6). It is a practice intended to carry out a radical change in our being. It is an exercise in which thinking takes itself as its own subject matter and seeks to modify itself (Hadot 1995, p.82), and thus to provoke a radical change in the individual. Yet, philosophy as a spiritual exercise is not situated merely on the cognitive level (Hadot 1995, p.83). It is a determinate way of living which engages the whole of existence; it is a conversion which turns our entire life upside down, changing the life of the person who goes through it. In sum, the object of spiritual exercise is to bring about the possibility of transformation.

In a course of lectures given in 1981 and 1982 entitled The Hermeneutics of the Subject, Michel Foucault built upon the concept of philosophy as spiritual exercise to affirm that it is only through what he calls the moment cartésien that philosophy in modern times turned out to be understood merely as a cognitive exercise (Foucault 2001, pp.2-39). In spirituality, however, there is no way of building knowledge or reaching truth which does not pass through a transformative practice or askesis of the self. Foucault relates this shift of philosophical practices to the concepts of "self-care" and "self-knowledge." While in ancient Greece "self-care" was a broader conception of the relation individuals have to themselves, of which "self-knowledge" was only a part or dimension, gradually throughout the centuries there was a movement that made "self-knowledge" the privileged relation to oneself, and one not necessarily tied to a moral or spiritual project of self-care. Each category affirms a different relationship to truth: while in a culture sensitive to "self-care" there is no way to access truth but through a moral discipline of the self, in the modern "self knowledge" culture, access to truth is merely a cognitive discipline which does not involve any transformation of the subject.

Within the context of a "self-care" culture, some ancient thinkers provided inspiring lists of spiritual exercises. For example, Philo of Alexandria left us with two lists that include the exercises of thorough investigation (skepsis), reading (anagnosis), listening (akroasis), attention (prosoche) and meditation (meletai). These spiritual exercises cultivate a way of seeing and being in the world. They do not entail the transmission of pre-determined knowledge from one person to another, nor do they constitute a methodology which guarantees epistemological certainty and existential security. Rather, the philosophical experience cultivated by spiritual exercise is an individual and shared journey of inquiry, discovery and transformation-one that calls oneself into thought, one's way of being in the world. It is such a journey that thirty adult students and two teachers in the city of Duque de Caxias decided to partake in.

\section{Spiritual Exercises in Duque de Caxias}

A short list of the spiritual exercises that were practiced in the adult literacy course in Caxias includes: the practice of asking questions that call oneself into wonder about being and the nature of the world, engaging in dialogue with oneself and 
others, cultivating a disposition that accepts uncertainty, doubt and mystery, exercises of "being a child" and "taking flight each day," and making oneself eternal by surpassing oneself (See Friedman 1970, p.359, cited in Hadot 1995, p.70).

These exercises were not the result of strict adherence to a prescribed teaching methodology. Nevertheless, some clarification is needed. In a sense, problematizing has been the core of our practice and informed the way we worked. During remarks that this was also the core of Aristotle's philosophical practice: "the most characteristic feature in Aristotle is his incessant discussion of problems. Almost every important assertion is an answer to a question put in a certain way, and is valid only as an answer to this particular question." (During 1964, pp.97-98, cited in Hadot 1995, p.105) Aristotle's method was to continuously problematize and approach each problem from different angles, each problem receiving contemplation specific to it. Socrates and other ancient philosophers were also adherents to this practice. "Such a method, consisting not in setting forth a system, but in giving precise responses to precisely limited questions, is the heritage - lasting throughout antiquity - of the dialectical method, that is to say the dialectical exercise" (Hadot 1995, p.106). Many contemporary philosophers, such as Bergson, also give importance to problematizing and the way one responds to each problem raised: "It is true that philosophy then will demand a new effort for each new problem. No solution will be geometrically deduced from another. No important truth will be achieved by the prolongation of an already acquired truth" (Bergson 1948, p.20). G. Deleuze, who was heavily influenced by Bergson, points out that philosophy consists in a three-dimensional activity: a) setting forth a plane of immanence; b) bringing a problem into this plane; c) creating a concept for that problem (Deleuze, Guattari 1994, pp.15-34). So, even though there was no prescriptive method to our philosophizing practice in Caxias, it was guided by the principle of problematizing.

In addition, all of the spiritual exercises in Caxias shared certain elements. Each began with the engagement of a text which had the ability to call the students into thought by provoking questions, which were discussed and ruminated on. Text, questions, and dialogue - three of the key elements present in all of the philosophical exercises in Caxias - were not meant to transmit pre-determined knowledge or guide the interlocutors to arrive at pre-determined epistemological objectives or goals. Rather, they were meant to cultivate an individual and shared thinking experience in which questions were more valued than answers, and doubts and uncertainties were expected to be more transformative than scholastic expertise. A brief inquiry into each of these elements follows.

\section{The Text (Texting and Self-Texting)}

Is it possible to work with texts in a class of students that cannot read or write? It is if we re-consider what we mean by "text". A text is anything that calls for interpretation or reflection. It can be a drawing, a picture, a photograph, a conversation, or a life situation that is reflected upon. Texts are signs that need to be interpreted and put into question in order to be more deeply understood. Moreover, the world and our individual and social experience of the world is, as Paulo Freire clearly demonstrated, a text that needs to be interpreted. In A Importância do Ato de Ler, Freire states: "The reading of the world precedes the reading of the word" (1992, p. 11). The world is a text and a critical reading of it enlarges our perception. Ontologically and epistemologically speaking, the reading of the world comes first: there is no way to give sense to a word without giving sense to a context that nurtures that word. At the same time, however, the reading of words continues and develops the interpretation of the world (Freire 1992, p.20).

In our course of adult students the stories and experiences that the group problematized were very much a product of the world that they had "read," and that they wanted to discuss and question with others. Following Freire, we might also speculate (we have no empirical evidence to support this) that this "reading" of the world, this problematizing of the world, and philosophically discussing the "world as text" with others, eventually leads to a more profound relationship with literacy, which, in turn, leads to a more profound relationship with the world. The world and words are read in a deeper way. One might say that our perception becomes more insightful after having had the chance to philosophize over the "world as text."

This type of "reading" has political implications. Freire states that the critical reading of reality, as part of a process of learning to read, associated with political mobilization practices, could make up a part of what Gramsci would consider counter-hegemonic actions (Freire 1992, p.21). Thus, philosophy as an exercise of critically reading reality opposes itself to other forms of education that foster conformity and maintenance of the status quo. It is a practice that empowers the subjects of this practice to have a much more complex and active relation to reality.

The act of reading the world as text is a singular experience of thinking, impossible to repeat exactly. When practiced with illiterate groups this is even more so the case. The oral nature of the texts and discussions make each experience with philosophy a new experience because the "text" changes as the participants in the experience change. As their reading of the world changes, their reading of the "words" also changes.

As such, the subjective dimension of the philosophical experience is reinforced. Philosophy re-enters its Socratic path as a living conversation directly addressed to a limited audience in an oral way. In the Phaedrus, Socrates points out some advantages of orality in contrast to writing. The subject can choose to whom he talks, while the author of a written text loses control over who has contact with the text-it is the reader who chooses the text she reads. Another advantage pointed out by Socrates is that oral discourse can be revised and corrected, while written text is fixed and impossible to alter. A third advantage is that oral conversation preserves 
memory while written text weakens it. All of these dimensions of oral texts could be experienced in our dialogues in Caxias. With these students, philosophy was an on-going process, a shifting back and forth, and hence a process of always recreating texts, thinking, and ways of living. Unknowingly, our group of students was revitalizing an ancient form of oral philosophizing.

In Caxias the "texts" that instigated our philosophical experiences were often the life experiences of the students themselves. Similar to oral communities that share wisdom and knowledge through story-telling, our dialogues often involved students relating paintings, photos and songs to their personal life experiences and then problematizing them individually and as a group. Individual life experiences became the "texts" that created communal philosophical experiences.

The word "text" has the root meaning "to weave" and it is, Walter Ong tells us, "more compatible etymologically with oral utterance than is "literature' which refers to letters (etymologically/literae) of the alphabet" (Ong 2002, p.13). Oral discourse is a form of weaving or stiching--rhapsoidein, rhapsodizing - which basically means stitching songs together (ibid). Adult literacy courses that foster dialogue as a means of learning and sharing wisdom have something in common with the ancient Greek concept of rhapsodizing. The human experiences that are stitched together and "sung" in oral communities become texts that are capable of provoking questions that call the community into thought and that put them on the way to philosophizing. Thus, it is possible to say that the creation, interpretation and discussion of such texts are practices that can be considered spiritual exercises. According to the Italian philosopher Giuseppe Ferraro, these exercises do not simply mean procuring a meaning that is present in a text; they also involve the reader finding her own voice in the text (Ferraro 1990). Our practice of oral philosophizing in Caxias therefore involved exercises of self-texting: encountering one's voice in the text that the world offers.

\section{Questions (Questioning and Self-questioning)}

If philosophy means, as Karl Jaspers has claimed, to be "on the way" then we must ask what puts us "on the way" (Jaspers 1959, p.12). Or if we associate philosophy with a kind of thinking that puts us "on the way," we might ask "what is it that calls us into thought?" In the ancient Greek tradition, we are put "on the way" by philosophical questions. Our being in the world needs to be questioned if we are to have a thoughtful and meaningful existence. Philosophical questioning concerns itself with this being, with the way we interact with the world and our experiences in the world. Every experience becomes a potentially boundless experience when it is put into doubt, but is de-limited by the philosophical question. Thus our experiences with the world, with ourselves, and others are completely changed by the act of asking philosophical questions. We begin to see and interact with the world, ourselves, and others differently only after we have questioned them. According to
Foucault, Socrates' task of making others question themselves was a way of provoking them to care for themselves (Foucault 2009 , p. 83). We could also say that questioning the world around us makes us break with our habitual way of inhabiting the world, and opens the possibility for caring for the world. Finally, questioning other people and our relations with them makes us re-think how we relate to them. In short we can say that putting our lived experience and our being under question is a spiritual exercise that is a potentially transformative experience.

It is of great importance to note that the journey of questioning/problematizing, is of greater importance than arriving at a final destination. What matters, according to Hadot, "is not the solution of a particular problem, but the road travelled to reach it" (Hadot 1995, p.92). Hadot argues that this emphasis of journeying with questions is clear in Plato's dialogues. One "spends a long time in the company of these questions and expands great effort, in which one "rubs names, definitions, visions and sensations against one another" (Hadot 1995, p.92, referencing Letters VII, 344b; 341c-d). This relationship with questions is exemplified in Plato's so-called Socratic Dialogues and also in some of the later dialogues like the Statesmen (285c-d). Socrates affirms that he has nothing to teach, no knowledge or content (mathema) to transmit (Apology 33a-b). Nevertheless, he is committed to continuous questioning and dialogue with others, the purpose of which is not arrival at a pre-determined answer but the therapeutic practice of dialogue itself.

Ruminating on philosophical questions within the context of our work in Caxias we can expand upon what it means to be "on the way" in philosophy. Very often external observers have asked us: "are these questions that the students are asking philosophical? What is a philosophical question then?" In response we affirm that if philosophy is a spiritual exercise, then it is not the questions themselves that are philosophical or not philosophical. Rather, what we tried to cultivate in Caxias was a philosophical relationship to questions, a certain spirit that would allow questions to question our being in the world, to let ourselves be questioned and eventually transformed by journeying with the questions themselves. We fostered questioning and self-questioning. More than the act of asking philosophical questions, what the spiritual exercise of questioning cultivates is a state of "being in question." In this sense, the art of self-questioning (not questioning something external, but putting oneself in question while questioning) is the core of our practice.

By far the greatest challenge of the Caxias project was the difficulty students had in forming questions which would provoke this kind of self-questioning and, at the same time, sustain philosophical dialogue. Asked to form questions about a text, or to each other, students often responded by making declarative statements. At the beginning of the course many students could not even clearly distinguish assertions from questions. Influenced by an educational system that focuses mainly on "functionalism/production/training," and by 
religious and political institutions that nurture sets of dogmas and not forms of inquiry, some of the students in the class remarked that they were being asked and encouraged to form questions for the first time in their lives. In the beginning of the course, when, on rare occasions, students did create questions, the questions were typically of two types: questions that only demanded affirmation or negation (yes/no answers) or questions that sought to flush out details or immediately resolve doubts on a particular text. It was nearly five months into the course when students began to create questions that would provoke and maintain real challenges to their experience, questions that would "break open" their experience. It was only then that we could say a philosophical relationship to questions and a deep experience of thinking was underway.

There is no methodology or formula that can be applied to teach someone how to ask philosophical questions, or that can be used to provoke someone to enter into a philosophical relationship with questions. Philosophy begins with wonder, in both senses of the word - awe and doubt - because it is wonder that inspires us to ask and to ponder. In Caxias we simply tried to nurture wonder. But how does one nurture wonder? Wonder is nurtured by cultivating attention (prosoche), by allowing students to dwell in thinking. Attention, according to Hadot, is key to spiritual exercise. It is continuous vigilance and presence of mind, a constant tension of the spirit (Hadot 1995, p.84). Attentive to the infinite value of each moment, we respond "immediately to events, as if they were questions asked of us all of a sudden" (Hadot 1995, p.85). We found that after months of attentively dwelling with paintings, music, conversation, and poetry shared by teachers, questions had to be asked. The call to thinking was too strong, the wonder too great. And so the students asked, and asked, and did not stop asking.

To live comfortably with uncertainty, mystery and doubt, without irritable reaching after fact and reason, establishes what Susan Wolfson has called a "questioning presence" (1986, passim). The English Romantic poet John Keats (17951821) called this disposition negative capability (Keats 2001, p. 492), and it is this trait that distinguishes the great poets like Shakespeare, Goethe and Milton, and the great philosophers like Socrates, Nietzsche and Foucault from their colleagues. This questioning disposition is as fundamental to experiencing philosophy as it is to experiencing poetry, and the teachers and students in Caxias were asked from the first to the last moments of their philosophy course to nurture negative capability. A year-long experience of constant questioning rather than receiving answers, of living with doubts rather than certainties, of looking at reality as something mysterious rather than as something fixed and anesthetic, transformed the dispositions of the teacher and student participants in the project. It might explain why so many of our moments were poetic as much as they were philosophical.

\section{Dialogue (Being Dialogued and Being in Dialogue)}

During a moment of reflection on the course, Dona Andrezza, age 54, shared with the class that she "felt empty after our encounters, philosophy was emptying me out." This was a striking observation that captures the profundity of the dialogues that occurred throughout the course. It also recalls many of Socrates' dialogues in which, rather than "fill" his interlocutors with knowledge, Socrates makes them question many of their beliefs and then discard them. This suggests that philosophical dialogue is often an experience of emptying ourselves out rather than filling ourselves up. Those who dialogue with Socrates do not learn something they did not know before; they learn that they do not know what they thought they knew. In a sense, like Dona Andrezza, they are "emptied".

Contemporary Brazilian poet Manoel de Barros expresses this nicely: "Unlearning eight hours a day teaches the principles [of] a didactics of invention" (De Barros 2000, p.9). In our teacher education courses this was a constant testimony of the teachers: the more they became engaged in philosophy the more clearly they could understand their journey with philosophy as an unlearning process. This experience of unlearning was complemented by, and related to, the spiritual exercise of "becoming a child," presented in de Barros' book Exercises of being a child (1999). de Barros shows how we can learn from practicing a childish way of being in the world, in that children are accustomed to being less "full," "fresher," less prejudiced, and more open to freely put themselves into question. Engaged in this exercise of "being a child," students in Caxias were asked to try to do some activities-painting, drawing, making questions - as a child does them, as if they had never done these things before, as if they were doing them for the first time, as if anything were possible. Vinicius, age 57 , captured the essence of this exercise nicely in one of our sessions when he told us that he was forming questions for the first time and that he felt as if he hadn't asked any questions in his life before.

This Socratic approach to the practice of philosophy has eminent pedagogical consequences. As Foucault stressed in his last course at the Collège de France, Le courage de la vérité (1984), devoted to the death of Socrates, the Athenian radically re-positioned the scope and sense of being a teacher. Where the traditional teacher said to the student: "You do not know and I know. Therefore, I will teach you so that you learn what you do not know," Socrates says: "You do not know, but I do not know either. So I will help you to take care of what you do not care about" (Foucault 2009, pp. 131-143). When Socrates' interlocutors think they know what they really do not know, Socrates' teaching consists in de-constructing this pseudoknowledge. In his final Apology before the Athenian tribunal, Socrates deemed the judgment against him as a judgment against a philosophical life. He explained that his wisdom did not consist of any positive knowledge but of a singular relationship to knowledge that demanded he not delude himself regarding the impossibility of human beings having any certain knowledge. He reasoned that if, as the oracle had proclaimed, 
he were truly the wisest man in Athens, it was because he was the only one who did not believe he knew anything for certain, aside from his own lack of knowledge.

To be sure, the majority of our students, particularly at the beginning of the course, were expecting to be "filled" with information and beliefs. Accustomed to being told what to think and believe by their churches, political figures, bosses at work, teachers at school and others, the process of participating in "emptying" rather than "filling" was at first painful and frustrating for many of the students. On more than one occasion students complained of "not learning anything," of having teachers that "don't teach." But dialogue as spiritual exercise "guides the interlocutor towards conversion" (Hadot 1995, p.93) and eventually our dialogues as "emptying" experiences began to provoke a transformation in the students of the course.

To put it in Socratic terms, this transformation has to do with that which we care for. This also implies a transformation of the function of the teacher. As Foucault pointed out in the case of Socrates, the teacher of philosophy occupies a paradoxical position in terms of care. Socrates dialogued with everyone so that they would stop caring about the exterior-richness, fame, honors, etc. - and would be moved to care for what is interiorthe soul, the truth, the good. One might interpret care for the self as an egocentric or individualistic movement, but Socrates' intention was quite the contrary. He wanted people to give importance to that which is most important in the individual and collective dimensions of life. In fact, Socrates materialized this project in his own life: he was the only one who did not care about himself ipsus litere because he was continuously concerned with others caring about themselves. Yet, in another sense, he took care of himself in the deepest way possible: as a teacher, as a spiritual leader, as a philosopher-someone who helps others to take care themselves.

Our communal experiences of dialogue in school led to another spiritual exercise concerning the care of self and others: meditation as dialogue with oneself. There is, argues Hadot, an "intimate connection between dialogue with others and dialogue with oneself. Only he who is capable of a genuine encounter with the other is capable of an authentic encounter with himself, and the converse is equally true" (Hadot 1995, p.91). Self-dialogue is not merely an encounter, but a confrontation with oneself. Hadot describes it as a "battle," amicable, but real. Though not eristic, every spiritual exercise is dialogical in this self-confrontational sense.

In Caxias we were able to see that dialogue with oneself and with others makes us unlearn what we have learned in a traditional way. Participants in our course came to question the relationship they had with knowledge, as something settled that they needed to receive. This kind of relationship had to be unlearned in order to build a new one: a questioning and dialogical relationship with knowledge. The same could be said in relation to thinking. What the students in Caxias had to learn was to unlearn a relationship with their own thinking as something they could not create or sustain by themselves.
Dialogue allowed the students to actively think about, and put into doubt the circumstances that made them live the way they were living. They began to think in new ways and created a new relationship with thinking. The significance of such an experience is apparent in another statement made by Vinicius, who told one of his teachers: "For the first time in my life I am pondering the stars, what is beyond, rather than being constantly weighed down by my everyday concerns of money, work, family problems, and health." Emptied and lighter, Vinicius, like Cynic and Stoic philosophers before him, was able to "take flight" and begin pondering the cosmos.

One of the most obvious impacts our project had on the adult participants is that it led them to see, think about, and be in the world in a different manner. The Stoics distinguished three branches of philosophy: logic, physics, ethics - each concerned with an aspect of one's being in the world. Typically, spiritual exercises are placed in ethics, but this is too limiting (Davidson in Hadot 1995, p. 24). Hadot has demonstrated that within the Stoic tradition logic and physics were never merely areas of discourse, but were disciplines of the well-lived life (ibid). Incidentally, this is one of Hadot's critiques of Foucault: that Foucault placed spiritual exercises firmly in the ethical realm, but didn't explore their place in the realms of physics or logic (Hadot 1995, pp.206-215 and Davidson in Hadot, p.24). Hadot states that philosophical physics contains three levels of exercises:

- Contemplation as an end in itself. Serenity of soul, liberation from day to day worries.

- A transcending of individuality to come into contact with the cosmos.

- Contemplation of nature (the world) tears us away from everyday life. It makes us question received ideas (Hadot 1995, pp.103-104).

At each of these three levels it is possible to hear Vinicius talking! He could-for the first time! -liberate himself from day to day worries (level 1), he could ponder the stars (level 2) and could tear himself away from, and question daily reality (level 3 ). Vinicius had fully engaged in the spiritual exercises of the realm of physics.

\section{Political Impacts of Philosophy as a Way of Life in Duque de Caxias}

Spiritual exercises are part of a philosophical way of living that provokes a radical transformation of being. We cannot say with certainty that the students and teachers that participated in the "Em Caxias a Filosofia En-caixa?!" project now live philosophically. But we can say that through philosophical exercises the majority of students and teachers involved in the project had a radical opportunity to transform themselves. At the end of the course, when asked the question: "What does philosophy mean to you?" several students responded that philosophy had "taught them a lot." When pressed to expand 
on and clarify the response it became clear that the students lacked words to express their experiences with philosophy. Their experiences of sharing life experiences, of weaving oral texts, of questioning and dialoging as a group and individually, and of developing a doubting disposition that revealed a world full of mystery and intrigue, had produced individual and group experiences that were extremely intense and perhaps beyond words. These examples constitute evidence that philosophy cannot merely be discussed, written, or read about; it must be lived and felt.

Though all impacts of the project in Caxias may not be immediately apparent, upon reflecting on the project it is evident that it had certain political effects. Before discussing these impacts a clarification is needed: our practice was not designed to produce any particular political outcome. We invited students to think, but we did not demand that they think in a certain way or toward certain ideas, much less that their thoughts correspond to our thoughts.

Two examples might help us express the political dimension of the project. During one class Luiza told a story about how, because of philosophy and our discussions in class, she felt more strength to question her husband and demand that he justify some of his demands on her. On another occasion, Valerio gave an emotional account of how he now felt more power to question his bosses and people on the street who didn't treat him respectfully. He also appealed to other students in the class to do the same, exclaiming that because of philosophy they should feel the self-confidence to "speak to power." Putting these statements into different words we might say that what these students came to realize was that they were more powerful than they had always been told, and that they might have more power over the way that they live, more power to live as they desire - if not in all aspects of their lives, at least in some of them.

Reading the work of Hadot one comes across a passage from G.Friedman's La Puissance de la sagesse:

Take flight each day! At least for a moment, however brief, as long as it is intense. Every day a "spiritual exercise," alone or in the company of a man who also wishes to better himself.... Leave ordinary time behind. Make an effort to rid yourself of your own passions.... Become eternal by surpassing yourself. This inner effort is necessary, this ambition, just. Many are those who are entirely absorbed in militant politics, in the preparation for the social revolution. Rare, very rare, are those who, in order to prepare for the revolution, wish to become worthy of it. (Emphasis added.)

Is our course in Caxias part of the preparation for social/ political revolution? Does philosophy as we practice it have this role? Should it play this role? Is spiritual exercise in philosophy the preparation needed to bring about true social/political revolution? Though the political outcomes we documented in our project tended toward liberatory experiences, if we are really committed to self-questioning then we cannot settle these questions with one particular response. We must, rather, keep them alive as a way of constantly putting into question the meaning and sense of bringing philosophical spiritual exercises to public schools in Rio de Janeiro, Brazil.

\section{References}

Barros, Manoel de. (2000) O livro das ignorâças. (São Paulo: Record)

Barros, Manoel de. (1999) Exercícios de ser criança. (Rio de Janeiro: Salamandra)

Bergson, Henri. (1946) The Creative Mind: An Introduction to Metaphysics. Trans., Mabelle L. Anderson. (New York: Dover Publications)

Deleuze, Gilles and Guattari, Felix. (1994) What is Philosophy? Trans. Graham Burchell and Hugh Tomlinson, (New York: Columbia University Press)

Ferraro, Giuseppe. (1990) I giardini di Armida o della solitudine del filosofo. (Napoli: Athena)

Foucault, Michel. (2001) The Hermeneutics of the Subject: Lectures at the College de France, 1981-82. Trans. Graham Burchell, Ed. Frederic Gros, (New York: Palgrave Macmillan)

Foucualt, Michel (2009) Le courage de la vérité. (Paris: Gallimard)

Freire, Paulo. (1992) A Importância do Ato de Ler. (São Paulo: Cortez Editora)

Gadamer, Hans-Georg (2004) Truth and Method. Trans. Joel Weinsheimer and Donald G. Marshall. (London: Continuum)

Hadot, Pierre (2002) What is Ancient Philosophy? Trans. Michael Chase, (Cambridge: Belknap Press of Harvard University Press)

Hadot, Pierre. (1995) Philosophy as a Way of Life: Spiritual Exercises from Socrates to Foucault. Trans. Michael Chase, (Oxford: Blackwell Publishing)

Hadot, Pierre. (2009) The Present Alone is Our Happiness: Conversations with Jeannie Carlier and Arnold I. Davidson. Trans. Marc Djaballah, (Stanford, Stanford University Press)

Hadot, Pierre. (2006) The Veil of Isis: An Essay on the History of the Idea of Nature. Trans. Michael Chase, (Cambridge: Belknap Press of Harvard University Press)

Jaspers, Karl. (1959) Way to Wisdom. In Introduction to Philosophy. Trans. Ralph Manheim, (New Haven: Yale University Press)

Keats, John. (2001) Complete Poems and Selected Letters of John Keats. (New York: The Modern Library)

Ong, Walter J. (2002) Orality and Literacy. (New York: Routledge) Wolfson, Susan J. (1986) The Questioning Presence: Wordsworth, Keats, and the Interrogative Mode in Romantic Poetry. (Ithaca: Cornell University Press) 